\title{
Chlorodyne Dependence
}

\author{
R. R. PARKER, J. P. COBB, P. H. CONNELL,
}

Conlon described took $150 \mathrm{ml}$ or more daily over a period exceeding three years. They all showed marked physical deterioration and, in panticular, all had signs of peripheral neuropathy. Furthermore, he described a pioture of mental deterioration associated with episodes of acute psychosis. The British Medical fournal (1963) stated that there was "no evidence that chlorodyne addiotion is a widespread problem, but the severity of complications arising from it is such that the conditions of sale of this tinoture ought to be reexamined." An alternative course of aotion, it continued, would be to lessen its toxicity by reducing the chloroform content. No change in the conditions of sale was made but the chloroform content was reduced from $17 \%$ to $5 \%$ in 1967 and codeine $0.21 \% \mathrm{w} / \mathrm{v}$ was omitted from the original formula.

Our recent experience in one London drug clinic suggests that chlorodyne addiction is a significant problem. Whereas 10 years ago the patients described were all over 40 years of age chlorodyne addiction is now also a problem in young people. We present eight illustrative case reponts (see table). We also repont the results of a questionnaire which we sent to seleoted pharmacists in London to try to obtain a rough estimate of the prevalence of chlorodyne addiction.

\section{Case Reports}

Case 1.-The patient was a 45-year-old man who until four years before had had a good work record as an office manager. He had been discharged from the armed Forces during the second world war because of "neurosis and inadequate personality." $\mathrm{He}$ had been taking chlorodyne for five years, initially "as a cure for hangovers" and at a time when his mother was dying of cancer. After one unsuccessful hospital admission he remained, in his own words, "a slave to Collis Browne." In two years his consumption increased to two bottles daily. Since the age of 26 he had drunk up to 18 pints $(10 \cdot 21$.) of beer daily but he reduced this as he took more chlorodyne. When seen by us he was taking up to 10 bottles $(250 \mathrm{ml})$ of chlorodyne daily. If without it for more than 12 hours he developed severe abdominal pain, retching, dyspnoea, and shakiness. He was sleeping badly and had been impotent for three years. His second marriage had recently broken up and his work was suffering. He spent one and a half hours each day walking from chemist to chemist buying one or two bottles of chlorodyne from each. There were no symptoms suggesting peripheral neuropathy or psychotic episodes.

Drug Dependence Clinical Research and Treatment Unit, Bethlem Royal Hospital and Maudsley Hospital, London SE5 8AZ

R. R. PARKER, B.A., M.R.C.PSYCH., Registrar

J. P. COBB, B.A., M.R.C.P., Registrar

P. H. CONNELL, M.D., F.R.C.PSYCH., Director

Details of eight Patients dependent on Chlorodyne

\begin{tabular}{|c|c|c|c|c|c|c|c|c|c|c|c|}
\hline \multirow{2}{*}{$\begin{array}{l}\text { Case } \\
\text { No. }\end{array}$} & \multirow{2}{*}{$\begin{array}{l}\text { Age } \\
\text { and } \\
\text { Sex }\end{array}$} & \multirow{2}{*}{$\begin{array}{c}\text { No. of } \\
\text { Years } \\
\text { on } \\
\text { Chloro- } \\
\text { dyne }\end{array}$} & \multicolumn{2}{|c|}{$\begin{array}{l}\text { Maximum Daily } \\
\text { Consumption }\end{array}$} & \multicolumn{3}{|c|}{$\begin{array}{l}\text { Consumption of } \\
\text { Other Drugs }\end{array}$} & \multirow{2}{*}{ Psychiatric Diagnosis } & \multirow{2}{*}{ Physical Symptoms } & \multirow{2}{*}{$\begin{array}{l}\text { No. of } \\
\text { Inpatient } \\
\text { Cures }\end{array}$} & \multirow{2}{*}{ Outcome } \\
\hline & & & $\begin{array}{c}\text { Chloro- } \\
\text { dyne } \\
(\mathrm{ml})\end{array}$ & $\underset{(\mathrm{mg})}{\text { Morphine }}$ & $\begin{array}{c}\text { Alco- } \\
\text { hol }\end{array}$ & $\begin{array}{c}\text { Oral } \\
\text { Drugs }\end{array}$ & $\begin{array}{l}\text { I.V. } \\
\text { Drugs }\end{array}$ & & & & \\
\hline 1 & $45 \mathrm{M}$. & 5 & 250 & 60 & + & & & $\begin{array}{l}\text { Inadequate-personality } \\
\text { disorder }\end{array}$ & & $\begin{array}{c}1 \text { (own } \\
\text { discharge after } \\
2 \text { days) }\end{array}$ & Still dependent \\
\hline 2 & $26 \mathrm{M}$. & 3 & 250 & 60 & + & & & 一 & $\begin{array}{l}\text { Stomach cramps, } \\
\text { diarrhoea }\end{array}$ & $\begin{array}{l}1 \text { (own } \\
\text { discharge after } \\
3 \text { weeks) }\end{array}$ & Still dependent \\
\hline 3 & $27 \mathrm{~F}$. & $3 \frac{1}{2}$ & 75 & 18 & & + & & $\begin{array}{l}\text { Personality disorder, } \\
\text { anorexia nervosa }\end{array}$ & $\begin{array}{l}\text { Anorexia, menstrual } \\
\text { irregularities }\end{array}$ & 3 & Still dependent \\
\hline 4 & $26 \mathrm{M}$. & 9 & 250 & 60 & & + & & $\begin{array}{l}\text { Inadequate-personality } \\
\text { disorder }\end{array}$ & Stomach cramps, nausea & 3 & Still dependent \\
\hline 5 & $23 \mathrm{M}$. & 2 & $87 \cdot 5$ & 21 & + & + & + & Alcohol dependence & 一 & 1 & $\begin{array}{l}\text { Died of } \\
\text { overdose }\end{array}$ \\
\hline 6 & $49 \mathrm{~F}$. & 11 & 50 & 12 & & $+?$ & & $\begin{array}{l}\text { Aesthenic-personality } \\
\text { disorder }\end{array}$ & $\begin{array}{l}\text { Weight loss, "peripheral } \\
\text { neuritis," pigmentation, } \\
\text { vomiting, diarrhoea }\end{array}$ & - & Not traced \\
\hline 7 & $29 \mathrm{M}$. & 17 & 125 & 30 & & & & $\begin{array}{l}\text { Inadequate-personality } \\
\text { disorder }\end{array}$ & & 3 & $\begin{array}{l}\text { Still dependent } \\
\text { when sent to } \\
\text { prison }\end{array}$ \\
\hline 8 & $31 \mathrm{M}$. & 9 & 500 & 120 & + & & & $\begin{array}{l}\text { Inadequate-personality } \\
\text { disorder }\end{array}$ & $\begin{array}{l}\text { Restlessness, stomach } \\
\text { cramps }\end{array}$ & $\begin{array}{l}1 \text { (own } \\
\text { discharge after } \\
3 \text { davs) }\end{array}$ & Still dependent \\
\hline
\end{tabular}


Case 2.-This patient was a 26-year-old married man with no children. He had had several jobs but had been a caretaker for the past three years. When aged 15 he had taken amphetamines and by the age of 19 he was drinking up to 12 whiskies or the equivalent in beer nightly. He started chlorodyne, on a chemist's advice, for "stomach trouble" when he was 23. His consumption had increased to two bottles $(50 \mathrm{ml})$ daily when he was 25 . Severe abdominal pain, nausea, and diarrhoea led to his admission to hospital. The results of all investigations were normal apart from serum aspartate aminotransferase, which was $60 \mathrm{U} / \mathrm{ml}$. He doubled his intake of chlorodyne over the next five months, which resulted in rapid physical deterioration. For six months he spent the day apathetically slumped in a chair, leaving his flat only to visit chemists to buy chlorodyne. He ate little, slept poorly, and lost libido. On admission to hospital in May 1973 he was taking up to 10 bottles $(250 \mathrm{ml})$ of chlorodyne daily. On a withdrawal regimen of $90 \mathrm{mg}$ methadone daily he had intense craving together with severe abdominal pain, nausea, and diarrhoea. Nevertheless, he rapidly gained weight and improved physically. He discharged himself after three weeks and relapsed immediately.

Case 3.-This patient was a 27-year-old woman whose father had a history of depressive illness. She had a university degree but subsequent jobs were short-lived and menial. She had had menstrual irregularities associated with episodes of anorexia alternating with overeating since she was 18 . She made a suicide attempt by slashing her wrists in 1969. Her recent marriage was unsuccessful. She took three tablets of phenmetrazine (Preludin) daily for nine years, which were replaced by chlorodyne in 1970 "to escape from mv problems." Her consumption rose from $12.5 \mathrm{ml}$ to three bottles $(75 \mathrm{ml})$ daily. After three unsuccessful inpatient treatments she continued to buy chlorodyne in increasing amounts.

Case 4.-This patient was a 26-year-old man whose parents both drank excessively and whose father suffered from depression. His school record suggested "unrealized potential" and his early work record was erratic. He suffered from asthma as a child. In his early teens he was dependent on amphetamines and took lysergide and caffeine. He was socially inadequate. He started taking chlorodyne when he was 17 after reading about it in chemistry books, and he learned to heat up chlorodyne to drive off the chloroform. He rapidly increased his dose to eight bottles daily and if he went without he experienced severe abdominal pain and nausea. After long outpatient treatment and three admissions to hospital he stabilized his needs to either three bottles $(75 \mathrm{ml})$ of chlorodyne or $30 \mathrm{mg}$ of methadone linctus daily, but he increased the dose in times of stress and preferred chlorodyne to methadone. His recent work record had been stable but he was separated in 1972 after five years of marriage.

Case 5.-This patient had started drinking alcohol when aged 15 and by the time he was 21 he was drinking spirits heavily. In his teens he occasionally took amphetamines, cannabis, and lysergide. From the age of 19 he took methadone and barbiturates intravenously. He was admitted to hospital many times for accidental overdoses, and drug taking led to his discharge from the armed Forces when he was 19. He stopped drinking alcohol while an inpatient for alcohol dependence when he was 21 but he surreptitiously bought Collis Browne's Compound when under stress. He took up to three and a half bottles $(87.5 \mathrm{ml})$ dailv. Within a month of discharge he was injecting methadone and barbiturates but he was able to substitute chlorodyne for methadone. He died from an overdose of tablets when he was 23.

Case 6.-This patient was a 49-year-old trained nurse. She first took chlorodyne when she was aged 38 and suffering from depression after her first husband's death. When she was 40 she was admitted to hospital with "neuritis and malnutrition." Over the next six years she took two bottles $(50 \mathrm{ml})$ of chlorodyne daily. She was admitted to hospital as an emergency case with a severe episode of diarrhoea and vomiting. She was cachetic and pigmented over the whole body, though not in the mouth, and she was profoundly hypokalaemic. She recovered rapidly but continued to take chlorodyne, increasing the dose at times of family stress. When she was 47 she was put as an outpatient on a methadone withdrawal regimen which was apparently successful but subsequent failed appointments suggested a possible relapse.

Case 7.-This 29-year-old man started drinking Collis Browne's Compound when he was aged 12 after it had been prescribed for him by a general practitioner for diarrhoea. He learnt to take chlorodyne to help him cope with stressful situations (such as his parents' impending divorce). He took up to five bottles daily and travelled extensively to buy supplies without arousing pharmacists' suspicions. Three attempts at an inpatient cure failed and he was still addicted to chlorodyne when he was committed to prison for petty crimes at the age of 28 .

Case 8.-This patient was a 31-year-old civil servant with a university degree. When aged 22 he was introduced to Collis Browne's Compound to ease stomach pains. When 24 he started drinking alcohol heavily but this decreased as his dose of chlorodyne rose to a maximum of 20 bottles $(400 \mathrm{ml})$ daily at the age of 26. By this time minor stomach upsets led to increasing absenteeism from work. Methadone withdrawal treatment as an inpatient when he was 28 was characterized by extreme agitation and stomach cramps, which he was unable to tolerate. Subsequent outpatient substitution of linctus methadone failed because he preferred chlorodyne.

\section{Pharmacists' Replies to Questionnaire}

Letters were sent to 48 pharmacists in central and south London who were known to our drug clinic. Information was requested about people who bought Collis Browne's Compound from them. They were asked to give (a) an estimate of the number of bottles of chlordyne they sold in a week; (b) the number of people buying chlorodyne each week; (c) particulars of people who bought chlorodyne regularly, with details of their age, sex, and the number of bottles they bought each week; and $(d)$ any other relevant details and comments. There were 15 replies.

Except for one large central pharmacy, which estimated it sold 120 bottles a week, the pharmacies sold an average of 13.4 bottles of chlorodyne a week to an average of eight people. The large central pharmacy could not be sure of the number of people buying Collis Browne's Compound because of its 24-hour shift system. The other 14 pharmacies recalled 13 people, six men and seven women, who bought chlorodyne regularly. They were nearly always described as being "middle-aged" or "elderly." Neventheless, one woman was said to be aged 22, another 25-30, and one man 35-40.

Many pharmacists made it plain that they were aware of abuse and dependence on chlorodyne and that dependent persons often used several chemists. They were generally wary of suspected abusers and some adopted a policy of not serving suspects. The pharmacy that sold 120 bortles a week commented that many of its customers were young people aged 18-25, which contrasted with the description given by smaller pharmacies.

\section{Discussion}

Previous authors (Seager and Foster, 1958; Conlon, 1963) described a group of middle-aged patients who were dependent on chlorodyne. We have shown that chlorodyne dependence is now a problem in young people since six out of eight of our patients became dependent on the drug before the age of 23. The pharmacists' replies indicate that there are young people in central London who buy chlorodyne. A rough estimate. based on these replies suggests that, since each pharmacy has an average of one regular customer and since there are some 1,150 pharmacies in Greater London, the total number of chlorodyne-dependent persons may well exceed 1,000 .

In none of our eight cases was there a fully-established cure. This poor prognosis may be due to several factors; the most impontant may well be that the drug can be bought cheaply without prescription. Another factor may be the considerable discomfont these patients experienced during methadone withdrawal treatment. In such withdrawal regimens the substitute drug is in doses equipotent to that of the morphine in the chlorodyne. Perhaps regimens allowing larger doses of methadone linotus or a graduated withdrawal from chlorodyne itself would be preferable, and we are investigating this. 
The severe side effeots reported by others-for example, peripheral neuropathy and psychosis-were not seen in our patients. This could theoretically have been because of the reduced chloroform content of the mixture. Previous reports, however, were published before the current analytical techniques for detecting the presence of various drugs in the urine were available and it may well be that the patients in previously reponted cases of chlorodyne abuse were taking other drugs such as amphetamines, barbiturates, or alcohol without investigator knowing. The question arises whether chlorodyne dependence is a widespread urban problem. The manufacturers claim to sell $1 \frac{1}{2} \mathrm{~m}$ bottles a year (equivalent to $9.0 \mathrm{~kg}$ of morphine) and a Glasgow pharmacist was recently struck off the Register for overselling chlorodyne (Finer, 1973). The propontion of the total amount of the drug manufactured which is used in bona fide therapeutics is unknown but our evidence suggests that abuse is commoner than has been suspected. Probably only a small propontion of chlorodynedependent people reach medical supervision.

\section{Conclusions}

Chlorodyne dependence affects the young as well as the middle-aged and its extent has been underestimated. Doctors and pharmacists need alenting to this problem. The prognosis in terms of giving-up the drug seems to be very poor and further work needs to be done to establish a satisfactory withdrawal regimen. In the light of our findings we recommend placing the supply of chlorodyne under some form of control.

Requests for reprints should be sent to P. H. Connell, Drug Dependence Clinical Research and Treatment Unit, Bethlem Royal Hospital and Maudsley Hospital, London SE5 8AZ.

\section{References}

British Medical fournal, 1963, 2, 1284.

Conlon, M. F. (1963). British Medical fournal, 2, 1177.

Finer, A. (1973). Sunday Times, 15 August.

Poisons and T.S.A. Guide, 1971, ed. L. Priest, 10th edn. London, Pharmaceutical Press.

Seager, C. P., and Foster, A. R. (1958). British Medical fournal, 2, 950.

\section{MEDICAL MEMORANDA}

\section{Idiopathic Hypoparathyroidism Presenting as Dementia}

\section{DENNIS ERAUT}

British Medical fournal, 1974, 1, 429-430

Idiopathic hypoparathyroidism is a relatively rare condition and is believed to occur mainly in children and young adults (Steinberg and Waldron, 1952; de Mowbray et al., 1954; Bronsky et al., 1958; Kopin and Rosenberg, 1960). The present case is of particular interest as the patient, an 80 -year-old man, was completely demented on admission but was discharged after treatment well and with normal, rational behaviour.

\section{Case Report}

An 80-year-old-man was admitted to hospital in December 1972 because he had been falling about at home. On admission he was unable to give any history or account of himself. His wife said that he had been deteriorating for many months and had been very confused and forgetful for a long time.

Previously he had been well until April 1971, when he complained of a deterioration in vision for two years. He was found to have bilateral cataracts, which were extracted in April (right) and October (left) 1971. He was admitted for a short period in February 1972 complaining of malaise and frequent belching and was noted to have early dementia; no cause was found for his gastrointestinal symptoms on barium-meal examination or gastroscopy.

On examination he was found to be completely disorientated in time and space. He was unable to respond to commands though could answer simple questions. There were no abnormal neurological signs but he had a raised temperature and signs of a chest infection and there were scattered bronchopneumonic changes on the chest $x$-ray film. The chest infection responded to Septrin

Guy's Hospital, London SE1 9RT

DENNIS ERAUT, M.B., M.R.c.P., Medical Registrar (Present address: London Chest Hospital, London E.2) (co-trimoxazole) but he remained demented. His answer to any question was "not bad," and he spent a large part of the day walking up and down the ward, colliding with objects and people.

Three weeks after admission he had a grand mal convulsion. There were no further abnormal neurological signs and the skull $x$-ray picture was reported as normal apart from some calcification in the carotid syphon. He was started on phenytoin $100 \mathrm{mg}$ thrice daily. Seven days later he was noted to be totally unresponsive, and was lying in bed with a Parkinsonian tremor of the hands. This was followed by a period of tetanic spasm of the left hand accompanied by a degree of stridor. The combination of tetany, cataracts, convulsions, and Parkinsonian features suggested hypocalcaemia and possibly hypoparathyroidism. He had no skeletal malformations of pseudohypoparathyroidism; he was a tall man with a thin face.

Investigations were: calcium $5.9 \mathrm{mg} / 100 \mathrm{ml}$; phosphate 5.6 $\mathrm{mg} / 100 \mathrm{ml}$; alkaline phosphatase $23 \mathrm{~K} . A$. units; protein $7.1 \mathrm{~g} / 100$ $\mathrm{ml}$ (albumin $3.5 \mathrm{~g}$, globulin $3.6 \mathrm{~g} / 100 \mathrm{ml}$ ); electrophoresis, normal pattern; bilirubin $0.4 \mathrm{mg} / 100 \mathrm{ml}$; serum aspartate aminotransferase $15 \mathrm{IU} / \mathrm{l}$; magnesium $1.8 \mathrm{mg} / 100 \mathrm{ml}$; sodium $133 \mathrm{mmol} / \mathrm{l}$; potassium $4.2 \mathrm{mmol} / 1 ; 24$-hour urinary calcium $2.1 \mathrm{mg} / 100 \mathrm{ml}$.

Electrocardiograms showed a prolonged Q-T interval $(0.5 \mathrm{sec})$ in lead aVL, where no $U$ wave was present. The $Q-T c$ was $0.51 \mathrm{sec}$ and is not usually more than $0.38 \mathrm{sec}$ at rates of $60-80$. In the absence of heart disease, drugs, and hypokalaemia this was thought to be an indication of hypocalcaemia. These changes were present on the electrocardiog:am taken in February 1972.

$X$-ray examination showed no evidence of rickets or osteomalacia. A three-day faecal fat estimation was $8.3 \mathrm{~g} /$ day, but there seemed no clinical cause for malabsorption; he did not have diarrhoea and a jejunal biopsy specimen was normal. A repeat collection showed 4.1 g/day (normal). Tests for autoantibodies including parathyroid antibody all gave negative results. An assay for parathyroid hormone failed to detect the presence of any hormone.

Trea'ment.- He was given intravenous calcium followed by dihydrotachysterol $1 \mathrm{mg}$ twice daily and Calcium Sandoz one tablet three times a day. After a few days he showed considerable mental improvement and his serum calcium started to rise. After three weeks the serum calcium was $8.0 \mathrm{mg} / 100 \mathrm{ml}$, phosphate 4.8 $\mathrm{mg} / 100 \mathrm{ml}$, and alkaline phosphatase $17 \mathrm{~K} . \mathrm{A}$. units. He was stabilized on calciferol $1.25 \mathrm{mg}$ daily and Calcium Sandoz one tablet three times a day. At the beginning of March 1973 the serum calcium was $9.4 \mathrm{mg} / 100 \mathrm{ml}$, phosphate $4.2 \mathrm{mg} / 100 \mathrm{ml}$, and alkaline phosphatase $11 \mathrm{~K}$.A. units; the 24-hour urinary calcium was $5.5 \mathrm{mg} / 100 \mathrm{ml}$. He was discharged home in March well recovered mentally able to walk steadily and to carry out a lucid conversation, and with reasonable memory for recent and past events; he showed a keen interest in his calcium metabolism. 